\title{
Sciendo
}

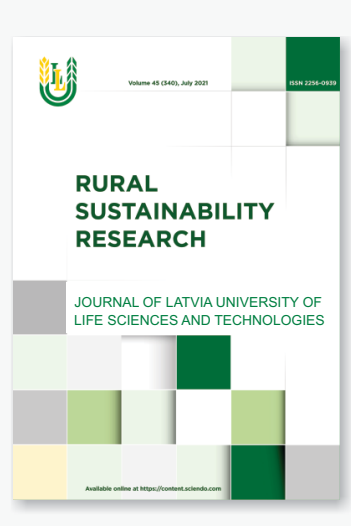

Received: 21 September 2021

Revised: 4 November 2021

Accepted: 8 November 2021

\section{Evaluation of patatin content in proteins of potato genotypes grown in Latvia}

\author{
*Dace Berga, Vita Sterna, Elina Sokolova, Inese Taskova, \\ Sanita Seile, Ilze Dimante, Ilze Skrabule \\ Crop Research Department, Institute of Agroresources \\ and Economics, 2 Zinātnes street, Priekuli, Latvia
}

\begin{abstract}
Potato proteins contains essential amino acids in considerably high concentration, therefore potatoes are considered to be one of the most valuable plant origin food for human consumption. Patatin forms one of the largest group of potato proteins with high potential to be used in food industry as a novel food. This study has been performed to approbate patatin determination method for evaluation of protein quality of potato genotypes, as well as evaluate patatin relative abundance (PRA) for breeding programmes to create in the future potato cultivars with higher value and potential to develop new products.

The evaluation of patatin was performed in following steps- extraction proteins from potato, determination of patatin concentration and calculation of its relative abundance in proteins. Separation of patatin from potato tubers was made using extraction by SDS extraction buffer and determination of patatin in organically and conventionally (with differnt $\mathrm{N}$ suply) grown samples of 20 potato genotypes. The results of one-year study showed that patatin relative abundance of different cultivars varied from $1.65 \%$ to $50.2 \%$ and it was significantly different among genotypes. The nitrogen content of soil and maturity type of potato did not affect PRA significantly. Results provide impetus for further research.
\end{abstract}

Key words: patatin relative abundance, potato genotypes, chip electrophoresis.

\section{Introduction}

One of the world's major and important crop grown in temperate zone and in other geographic territories is potato (Solanum tuberosum L.). Due to the growing population, climate changes and following deficiency of food, new and effective use of grown crop is the main challenge for coming years. Potatoes are commonly used in many countries as one of the main food crop, in which protein is the second major component after carbohydrates - (Bárta et al., 2012). Study of five potato varieties bred and grown in Latvia had shown that the protein content of the tubers before storage ranged from 1.3 to $2.0 \%$ of fresh weight (Murniece et al., 2011). Potato protein has great biological value even higher than soybean(Camire et al., 2009). Patatin, protease inhibitors and high molecular weight proteins are the three major groups of potato soluble proteins (Pots et al., 1999). The major component of potato protein is patatin, which makes about $40 \%$ of the potato soluble protein. Patatin belongs to group of glycoproteins within the range of molecular weight 40 to 45 kDa(Kärenlampi \& White, 2009). Most recent studies show, that patatin is not only a storage protein, but it has much more functional meaning such as enzymatic activity and it takes a part in potato defence regulation.-(Barta \& Bartova, 2008; Bartova et al., 2013). In review by Waglay et al. (2016) it is said that as plant origin protein patatin has high nutritional benefit which is equal to an egg albumen and have considerable emulsifying properties, better than soy proteins.

Patatin as a novel food has good prospects in food industry, where apart as foaming and emulsifying agent it could be used as gel former. During the past years, researchers are exploring the benefit of patatin on health and found several properties such as antioxidant, ACEinhibitory, anti-inflammatory and anticancer activities. Patatin stimulating glucose uptake and inhibiting neuropeptides.(Camire et al., 2009; Fu et al., 2020). Thereby further research directions could be selection of cultivars with improved nutritional quality of potato proteins.

To date, isolation of potato proteins had been performed in several ways. Main studies for industrial purposes are based on different protein isolation methods from potato tuber juice. The potato tuber juice is a side stream and 
available in large quantities in the starch industry (Fu et al., 2020). Extraction of proteins from tubers mostly is performed by SDS lysis buffer, which is more suitable compared to phenol extraction method due to the fact that the method is faster and provides much higher protein concentration in extract(Delaplace et al., 2006).

For research purposes to evaluate different potato cultivars, protein extraction has been made from freeze dried tuber meal. Further patatin determination has been performed by electrophoretic analysis (SDS - PAGE of denatured proteins) or chip electrophoretic analysis (Barta \& Bartova, 2008; - Barta et al., 2012).

It is considered that all genotypes of cultivated potato contains patitin (Lee et al., 1983) and, like protein content, depends on several factors, such as the genotype, stage of tuber development, storage duration and agro-ecological conditions during plant development (Pots et al., 1999; Lachman et al., 2005). Potato tuber yield is affected by the farming system and $\mathrm{N}$ availability in soil. Findings from previous research showed that nitrogen or protein concentration in tubers slightly increased, when $\mathrm{N}$ fertiliser had been applied at rates from 0 to $120 \mathrm{~kg} \mathrm{ha}^{-1}$, but remained constant with higher $\mathrm{N}$ fertiliser doses (Ruza et al., 2013). Although significantly lower content of total $\mathrm{N}$ has been detected in tubers grown under organic conditions (Bartova et al., 2013). It was observed that the farming system doesn't have considerable impact on the relative abundance of patatin in tubers (Bartova et al., 2013; Lehesranta et al., 2007), while nitrogenous compounds including proteins were strongly variety dependent (Bartova et al., 2013). The amount of several other substances have been compared in previous studies in potato tubers, which are grown in both conditions - organic and conventional. Predominantly higher amount of total phenolic compounds (Murniece et al., 2013), ascorbic acid (vitamin C) (Skrabule et al., 2013a) and thiamine (vitamin $\mathrm{B}_{1}$ )(Skrabule, et al, 2013b) was detected in tubers grown in organic fields.

Relatively few studies have been carried out on this topic in the world, and there are no research results on patatin content in potato genotypes grown in Latvia. Thereby the aim of this study was to evaluate approbated patatin determination method for comparison of protein quality of potato varieties, as well as to evaluate patatin relative abundance (PRA) for breeding programmes to create potato cultivars with higher value and potential to develop new products.

\section{Material and Methods}

\section{Description of potato growing conditions}

Twenty potato genotypes of different maturity were grown in fields of organic and conventional management in Priekuli branch $\left(57^{\circ} 19^{\prime} \mathrm{N}, 25^{\circ} 20^{\prime} \mathrm{E}\right)$ at the Institute of Agricultural Resources and Economics in 2020. The soil type in organic and conventional fields was sandy loam. The soil $\mathrm{pH}_{\mathrm{KCl}}$ in fields was in range 5.5-5.7 that is optimal for potato production. Plant available nitrogen $(\mathrm{N})$ in soil was $71 \mathrm{~kg} \mathrm{ha}^{-1}$ in organic trial field (Organic), and $69 \mathrm{~kg} \mathrm{ha}^{-1}$ in conventional field. The available phosphorus and potassium was medium in organic field, and high in conventional field. Three trial fields were arranged in conventional field, using different $\mathrm{N}$ supply: Conv1 - total available N - $129 \mathrm{~kg} \mathrm{ha}^{-1}$, Conv2 - 189 $\mathrm{kg} \mathrm{ha}^{-1}$, Conv3 $-249 \mathrm{~kg} \mathrm{ha}^{-1}$.
The climate conditions for potato vegetation were acceptable in 2020, during vegetation period total precipitation was $374 \mathrm{~mm}$ (98\% from long term data) and average air temperature $-15.02{ }^{\circ} \mathrm{C}$ (long term data exceeded by $3.3^{\circ} \mathrm{C}$ ).

Potato genotypes were planted in $3.4 \mathrm{~m}^{2}$ plots in four replications with a randomised plot layout in each trial field. Agronomic practices common in the area were used during vegetation season according to the requirements of organic and conventional farming. The tuber yield samples of genotypes from all trial fields were used for protein and patatin detection.

\section{Potato tuber test (sample preparation)}

Healthy tubers of average size were collected as primary samples from first and third replication of Organic, Conv1, Conv 2 and Conv 3 trials. The collected tuber samples were washed thoroughly and the average samples from each primary sample were prepared by cutting tubers longitudinally into four parts. The selected parts were homogenised and around $110-140 \mathrm{~g}$ of each average sample were immediately frozen at $-20{ }^{\circ} \mathrm{C} / 24 \mathrm{~h}$ and later dried by freeze - drying (Alpha 2-4 LDplus, Martin Christ Gefriertrocknungsanlagen $\mathrm{GmbH}$, Germany). Freeze drying parameters: main drying $-50{ }^{\circ} \mathrm{C}, 0.040 \mathrm{mBar}, 48 \mathrm{~h}$, final drying $8 \mathrm{~h}$, and finally the dry potato meal was homogenised repeatedly with a laboratory grinder. Lyophilized tuber material was used for the $\mathrm{N}$ content assay (crude protein analysis), tuber pure protein content determination by $\mathrm{BCA}$, and for protein chip electrophoresis analyses.

\section{Extraction}

The protocol used for protein extraction was taken from publication -Barta \& Bartova (2008), with slight deviations. The potato meal was used to extract pure protein by SDS extraction buffer $(0.062 \mathrm{M}$ Tris- $\mathrm{HCl}$ buffer, $\mathrm{pH} 6.8$, with $2 \%$ SDS). $1 \mathrm{ml}$ extraction buffer was added to $100 \mathrm{mg}$ potato meal, vortexed and stored at $4{ }^{\circ} \mathrm{C}$ for 4 hours. Extracted mixture was centrifuged (10 $\left.000 \mathrm{rpm}, 7 \mathrm{~min}, 4{ }^{\circ} \mathrm{C}\right)$, the obtained supernatant was placed in two $0.5 \mathrm{ml}$ microcentrifuge tubes, $100 \mu \mathrm{l}$ in each tube. The sample extracts were immediately frozen at $-20{ }^{\circ} \mathrm{C}$. One of the part was used for pure protein assay by BCA and the other part was used for patatin determination by Chip electrophoresis.

\section{Protein analysis}

Kjeldahl's method was used for determination of crude protein content, with conversion factor 6.25 to convert total $\mathrm{N}$ to crude protein.

BCA protein assay kit (Novogen, Germany) was used to assess pure protein content in protein extract prepared from potato meal. The basis of this method is biuret reaction $\left(\mathrm{Cu}^{2+}\right.$ reduced to $\mathrm{Cu}^{+}$by protein in an alkaline solution), and detection of obtained concentration of the monovalent copper ions by colorimetric method. The manufacturer's instruction was followed to perform analysis.

The concentration of proteins in the sample extracts must be between $0.2-0.95 \mathrm{mg} \mathrm{ml}^{-1}$ to be within the calibration range. Prepared potato sample extracts were diluted with extraction buffer $(10 \mu \mathrm{l}$ sample extract: $90 \mu \mathrm{l}$ extraction buffer). Calibration solutions were prepared according to the manufacturer's instruction. $25 \mu \mathrm{l}$ diluted sample extracts 
were mixed with $500 \mu \mathrm{l}$ BCA working solution, vortexed and incubated $37^{\circ} \mathrm{C}, 30 \mathrm{~min}$, cooled down to room temperature.

Colorimetric method was used to determine pure protein content in sample in triplicate at the wavelength of $562 \mathrm{~nm}$ by a spectrophotometer Nanodrop ND-1000 (NanoDrop Technologies, U.S.A). Due to exceeding of time to measure and record the absorbance of reactions the repeated measurements of the standard solutions were performed. Correction of calibration curve and measured reaction results was made accordingly.

\section{Chip electrophoresis}

Relative abundance of patatin (PRA) in total protein of potato tubers was determined from electrophoretic analysis. Electrophoresis of extracted proteins on a microchip was performed in the Agilent 2011 Bioanalyzer with the 2100 Expert Software. For analysis of proteins, the Agilent Protein Kit 230 was used (Agilent Technologies, Waldbronn, Germany), where quantification of proteins was between 14 $240 \mathrm{kDa}$. Manufacturer's protocol was followed for sample preparation and analysis of data.

Four microliters of protein sample were mixed with two microliters sample buffer with $3.5 \%$ ß-mercaptoethanol (BME) as reducing agent. The protein sample solution and diluted ladder were denaturated by heating to $95^{\circ} \mathrm{C}$ for $5 \mathrm{~min}$. Further samples were diluted with $84 \mu \mathrm{L}$ deionized water (Millipore). Six microliters of sample and ladder were loaded to the primed protein chip for analysis. The loaded protein chip was vortexed at low speed for 60 seconds to obtain more accurate assay results The automated data processing was performed using the software Agilent 2100 Expert, where molecular weight and relative protein concentration $\left(\mathrm{ng} \mu \mathrm{L}^{-1}\right)$ were calculated, and total value (\%) by means of the calculation of separated peak area from individual proteins in the sample. The manufacturer's instruction was followed to perform analysis in triplicate.

\section{Statistical analysis}

Descriptive statistics was used for the analysis of the obtained results (sample mean and standard deviation), ANOVA was applied for detection of genotype and farming system effects $(\alpha=0.05)$. Pearson's correlation was used to reveal relationship between variables. Analysis was made with programme software package SPSS, version 20.

\section{Results and Discussion}

According to the literature, patatin belongs to the group of glycoproteins and can be detected by SDS PAGE in area between $3944 \mathrm{kDa}-$ (Barta \& Bartova, 2008), or $4045 \mathrm{kDA}$ (Waglay et al., 2016), while chip electrophoresis indicates that patatin and its isoforms can be detected at $44-58 \mathrm{kDa}$ (Bartova et al., 2013). The results of this research showed, that patatin determination area was $4048 \mathrm{kDa}$ (Figure 1).

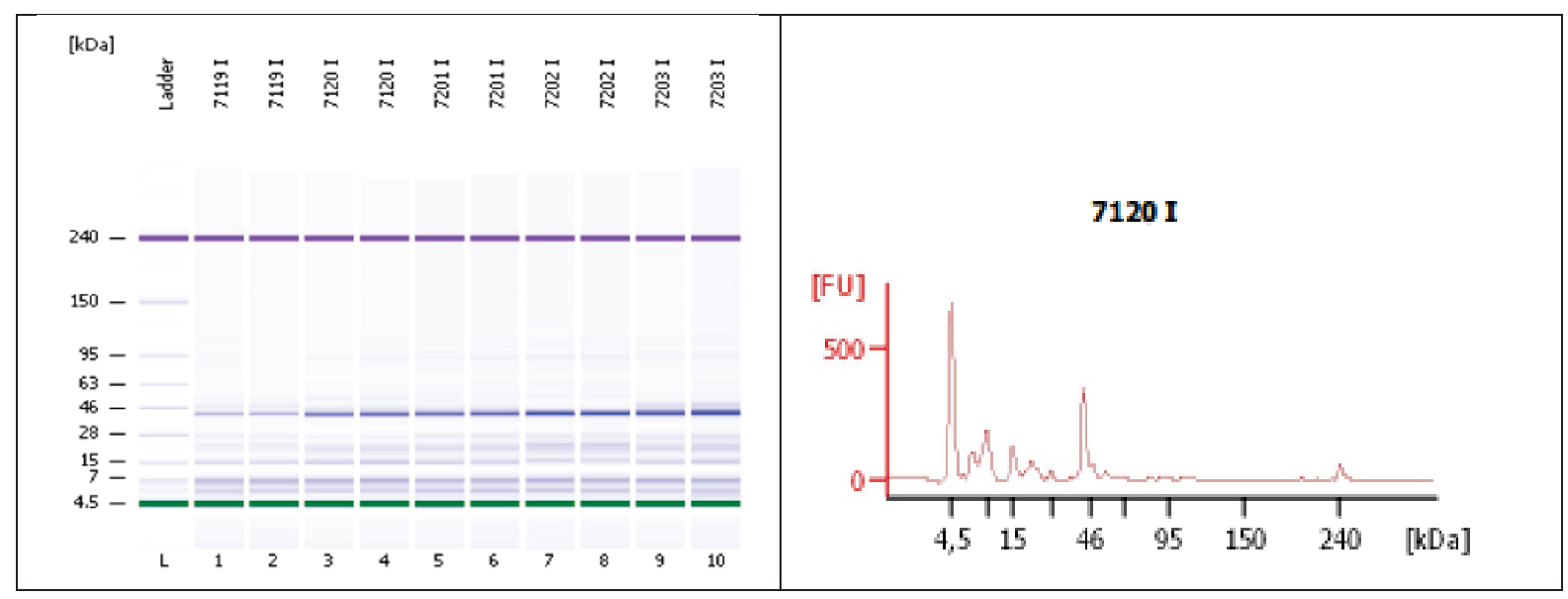

Figure 1. Area of patatin determination by Agilent 2011 Bioanalyzer.

The data obtained in the present study on PRA in potato tubers differ from the data in studies before by _ Barta et al., (2012) and Bartova et. al. (2013) due to the different detection methods. Within the mentioned studies, chip electrophoresis system Experion was used for the analysis (BioRad, USA) were patatin was quantified using protein kit Experion Pro260. Resolution and quantification of proteins was between $10-260 \mathrm{KDa}$. In the present study, the chip electrophoresis was performed using an Agilent 2011 Bioanalyzer with the 2100 Expert Software and the Agilent Protein Kit 230, where quantification of proteins was between $14-240 \mathrm{kDa}$.
Three quantification levels ( 40.6,41.8, and $42.9 \mathrm{kDa})$ of purified patatin were detected by MALDI-TOF MS within all genotypes in the study of Barta et.al. (2012). These studies indicated that individual isoforms of patatin vary in their masses and depends from particular potato genotype. Example of page image comparison of varieties 'Verdi'(713III) and 'Madara' (7202III) samples is shown in Figure 2. 

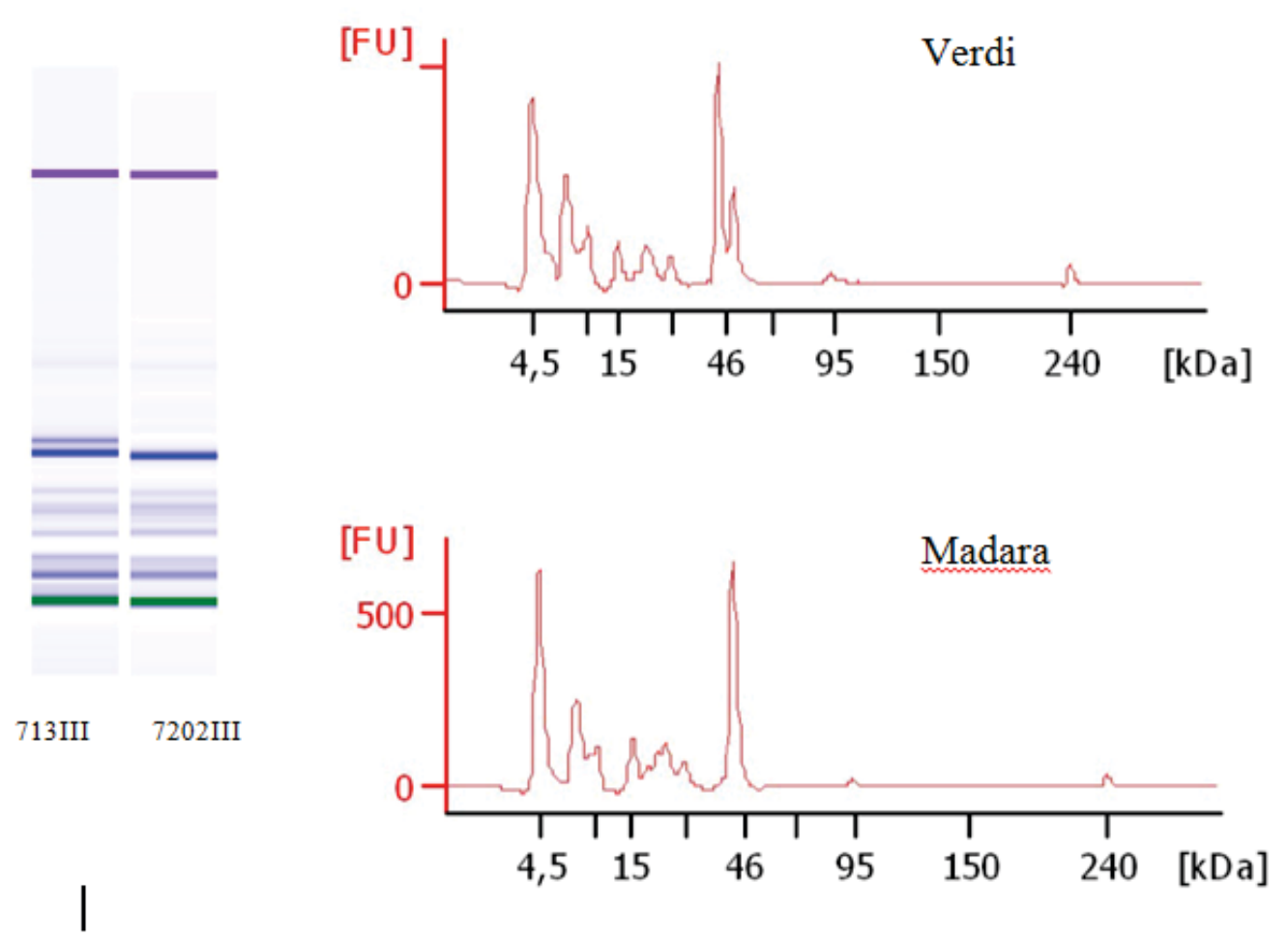

Figure 2. The comparison of patatin representation in genotypes 'Verdi' and 'Madara'.

The results of patatin relative abundance in the same potato sample formed dispersion of results, uncertainty was determined $8 \quad 10 \%$ and was recognized as valid for comparison of genotypes. The results of PRA in potato genotypes grown in different experimental conditions are summarized in Figure 3.

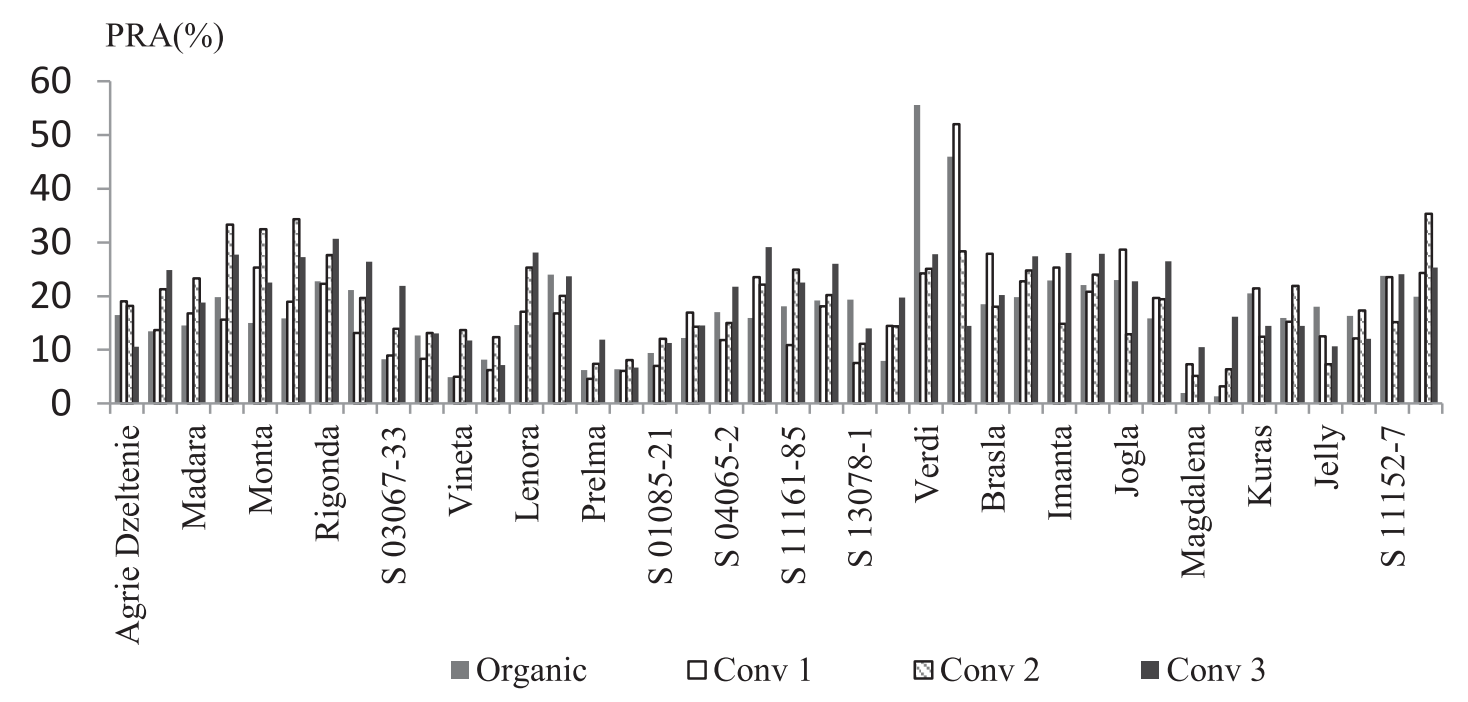

Figure 3. Patatin relative abundance in different potato genotypes from four growing conditions.

The results of patatin relative abundance in potato samples of different genotypes varied from $5 \%$ to $55 \%$ (Figure 3). The highest PRA was determined in variety "Verdi", but in the samples of genotypes 'Vineta', Prelma' and
'Magdalena' it was less than 10\%.

The comparison of average patatin relative abundance between potato genotypes from particular maturity classes are shown in Table 1. 


\section{Evaluation of patatin relative abundance (\%) depending on maturity class and growing conditions}

\begin{tabular}{|c|c|c|c|c|}
\hline \multirow{2}{*}{$\begin{array}{l}\text { Maturity classes and } \\
\text { genotypes }\end{array}$} & Organic & Conv 1 & Conv 2 & Conv 3 \\
\hline & \multicolumn{4}{|c|}{ PRA, $x \pm$ SD } \\
\hline $\begin{array}{l}\text { Early, } \\
\text { avarage }\end{array}$ & $13.61 \pm 4.82$ & $15.74 \pm 6.09$ & $22.36 \pm 8.43$ & $20.59 \pm 7.49$ \\
\hline Agrie Dzeltenie & $14.45 \pm 1.73$ & $16.33 \pm 3.36$ & $19.71 \pm 2.04$ & $15.32 \pm 8.25$ \\
\hline Madara & $16.28 \pm 3.22$ & $16.21 \pm 2.61$ & $28.33 \pm 7.71$ & $23.19 \pm 5.63$ \\
\hline Monta & $15.29 \pm 0.51$ & $23.20 \pm 4.06$ & $33.41 \pm 4.96$ & $24.89 \pm 2.99$ \\
\hline Rigonda & $21.95 \pm 1.12$ & $17.70 \pm 5.45$ & $23.64 \pm 4.69$ & $28.53 \pm 2.61$ \\
\hline S 03067-33 & $10.49 \pm 2.69$ & $8.63 \pm 0.45$ & $13.53 \pm 0.78$ & $17.49 \pm 5.37$ \\
\hline Vineta & $7.06 \pm 4.82$ & $5.64 \pm 0.88$ & $13.24 \pm 1.68$ & $10.18 \pm 2.75$ \\
\hline $\begin{array}{l}\text { Mid_early, } \\
\text { avarage }\end{array}$ & $\mathbf{1 9 . 4 2} \pm 14.24$ & $\mathbf{1 7 . 1 7} \pm 12.24$ & $\mathbf{1 8 . 5 0} \pm 6.74$ & $\mathbf{1 9 . 4 2} \pm 8.04$ \\
\hline Lenora & $19.31 \pm 5.67$ & $17.00 \pm 0.24$ & $22.65 \pm 5.54$ & $25.89 \pm 3.10$ \\
\hline Prelma & $6.32 \pm 0.67$ & $5.59 \pm 0.87$ & $7.73 \pm 0.51$ & $8.44 \pm 3.09$ \\
\hline S 01085-21 & $10.81 \pm 1.67$ & $11.99 \pm 5.89$ & $13.20 \pm 1.33$ & $12.93 \pm 3.42$ \\
\hline S 04065-2 & $16.47 \pm 1.39$ & $19.64 \pm 8.48$ & $18.52 \pm 5.74$ & $28.99 \pm 10.27$ \\
\hline S 11161-85 & $18.62 \pm 1.50$ & $14.51 \pm 4.16$ & $22.56 \pm 3.24$ & $23.67 \pm 2.00$ \\
\hline S 13078-1 & $13.65 \pm 7.07$ & $10.99 \pm 4.02$ & $12.72 \pm 1.99$ & $15.90 \pm 3.40$ \\
\hline Verdi & $50.79 \pm 6.32$ & $38.14 \pm 16.11$ & $26.71 \pm 2.09$ & $23.34 \pm 7.71$ \\
\hline $\begin{array}{l}\text { Mid_late_late, } \\
\text { avarage }\end{array}$ & $17.57 \pm 6.48$ & $19.91 \pm 7.59$ & $16.31 \pm 8.57$ & $20.76 \pm 6.54$ \\
\hline Brasla & $19.14 \pm 0.93$ & $25.30 \pm 3.30$ & $20.24 \pm 4.16$ & $22.60 \pm 4.23$ \\
\hline Imanta & $22.52 \pm 0.61$ & $23.09 \pm 2.87$ & $17.89 \pm 5.48$ & $27.94 \pm 0.38$ \\
\hline Jogla & $20.58 \pm 4.99$ & $25.66 \pm 5.62$ & $15.93 \pm 5.54$ & $24.64 \pm 2.76$ \\
\hline Magdalena & $1.65 \pm 0.42$ & $5.97 \pm 2.42$ & $5.77 \pm 0.93$ & $14.28 \pm 3.44$ \\
\hline Kuras & $18.23 \pm 3.35$ & $18.31 \pm 4.39$ & $15.60 \pm 5.98$ & $24.64 \pm 2.76$ \\
\hline Jelly & $15.07 \pm 4.04$ & $12.36 \pm 0.85$ & $13.98 \pm 5.76$ & $11.12 \pm 1.36$ \\
\hline S 11152-7 & $21.85 \pm 2.42$ & $23.95 \pm 3.37$ & $25.26 \pm 12.66$ & $24.51 \pm 1.97$ \\
\hline
\end{tabular}

The results of the study showed that there were significant differences in patatin relative abundance $(p<0.05)$ between potato genotypes. No statistically significant differences $(\mathrm{p}=$ 0.202 ) in PRA were detected between organic and conventional management systems with different $\mathrm{N}$ availability. Obtained results correspond to other studies, where the patatin relative abundance of evaluated genotypes significantly differed between cultivars and ranged from $5.4 \%$ to $35.40 \%$ (Barta et.al., 2012), or from $13.9 \%$ to $36.8 \%$ on dry matter basis (Bartova et.al., 2013), while the impact of growing system, year and field location was not found to be significant. Based on acknowledgments from study of Lehesranta et al. (2007), correlation between patatin relative abundance in potato tubers and farming system is not significant.

The highest level of patatin relative abundance was observed in samples of potato variety 'Verdi' (50.79\%) grown in organic field, in turn PRA amount of the same genotype in the conventional growing conditions decreased to $38.14 \%$; $26.71 \% ; 23.34 \%$, while $\mathrm{N}$ amount in the soil increased. The lowest level of PRA (PRA $=1.65 \%$ variety 'Magdalena') was determined in organic field also, but for this variety PRA increased in conventional conditions, where $\mathrm{N}$ availability in the soil increased. The reason for observed differences among growing conditions couldn't be found after evaluation of one year study, but heterogeneous structure of patatin could be one of them.

The amount of patatin relative abundance in variety 'Kuras' was from $15.6 \%$ to $24.64 \%$ in the present study (Table 1). Obtained results were in accordance with previous study where PRA in 'Kuras' variety varied from $15.03 \%$ to $23.10 \%$ (Barta \& Bartova, 2008). These findings demonstrate 
dominance of genetic traits over climatic or growing conditions. Barta \& Bartova (2008) reported that patatin content was significantly higher in processing potato varieties $(25.80 \%)$ than in ware varieties $(21.59 \%)$ and probably is related to the ability of genotypes to accumulate not only starch, but also patatin (Pots et al., 1999).

PRA and protein content in tuber samples of potato genotypes from particular maturity classes are shown in Table 2 .

\section{Crude protein, pure protein and patatin relative abundance of potato genotypes}

\begin{tabular}{|l|c|c|c|}
\hline \multirow{2}{*}{$\begin{array}{c}\text { Genotypes/maturity } \\
\text { classes }\end{array}$} & Crude protein & Pure protein & PRA \\
\cline { 2 - 4 } Early, average & \multicolumn{2}{|c|}{ \% DM } & \% pure protein \\
\hline Agrie Dzeltenie & $\mathbf{8 . 0 2} \pm 1.89$ & $\mathbf{5 . 6 2} \pm 0.95$ & $\mathbf{1 8 . 4 3} \pm \mathbf{7 . 7 1}$ \\
\hline Madara & $8.47 \pm 1.80$ & $6.13 \pm 0.95$ & $16.67 \pm 4.35$ \\
\hline Monta & $8.32 \pm 2.00$ & $5.12 \pm 0.59$ & $21.31 \pm 7.09$ \\
\hline Rigonda & $7.72 \pm 1.72$ & $5.01 \pm 0.46$ & $24.90 \pm 7.39$ \\
\hline S 03067-33 & $7.23 \pm 1.89$ & $6.40 \pm 1.22$ & $23.09 \pm 5.65$ \\
\hline Vineta & $7.76 \pm 2.12$ & $5.29 \pm 0.72$ & $13.09 \pm 4.43$ \\
\hline Mid_early, average & $8.62 \pm 1.69$ & $5.77 \pm 0.99$ & $9.34 \pm 3.45$ \\
\hline Lenora & $\mathbf{8 . 4 2} \pm 1.96$ & $\mathbf{5 5 9} \pm 1.01$ & $\mathbf{1 8 . 6 2} \pm 10.79$ \\
\hline Prelma & $7.09 \pm 1.02$ & $4.98 \pm 0.87$ & $21.49 \pm 5.21$ \\
\hline S 01085-21 & $8.97 \pm 1.97$ & $5.61 \pm 0.75$ & $6.90 \pm 1.84$ \\
\hline S 04065-2 & $7.35 \pm 1.37$ & $5.25 \pm 0.75$ & $12.23 \pm 3.34$ \\
\hline S 11161-85 & $7.65 \pm 1.41$ & $5.15 \pm 0.75$ & $19.78 \pm 6.91$ \\
\hline S 13078-1 & $10.79 \pm 2.27$ & $6.37 \pm 0.67$ & $13.15 \pm 4.44$ \\
\hline Verdi & $9.51 \pm 1.19$ & $6.77 \pm 0.69$ & $35.50 \pm 14.00$ \\
\hline Mid_late_late, average & $7.45 \pm 1.02$ & $5.00 \pm 0.98$ & $\mathbf{1 8 . 6 3} \pm \mathbf{7 . 4 6}$ \\
\hline Brasla & $\mathbf{7 . 7 1} \pm 4.99$ & $\mathbf{4 . 7 5} \pm 0.92$ & $22.33 \pm 3.96$ \\
\hline Imanta & $7.88 \pm 1.17$ & $5.68 \pm 0.87$ & $23.29 \pm 4.66$ \\
\hline Jogla & $10.59 \pm 12.21$ & $4.88 \pm 0.83$ & $21.93 \pm 5.64$ \\
\hline Magdalena & $6.20 \pm 1.61$ & $4.23 \pm 0.64$ & $7.26 \pm 4.88$ \\
\hline Kuras & $6.97 \pm 1.76$ & $4.46 \pm 0.74$ & $16.84 \pm 3.90$ \\
\hline Jelly & $5.23 \pm 1.18$ & $4.04 \pm 0.79$ & $13.28 \pm 3.55$ \\
\hline S 11152-7 & $8.05 \pm 1.73$ & $4.82 \pm 0.79$ & $23.84 \pm 6.36$ \\
\hline
\end{tabular}

The results of pure protein showed that average protein content in maturity group Mid_late_late was significantly lower $(p<0.05)$ than determined in samples from other maturity groups. Average crude protein content of maturity class Mid_late_late was lower $(7.71 \%$ of DM) than average of Early and Mid_early class $(8.02 \%$ and $8.42 \%$ of DM, respectively) but these differences were no statistically significant ( $p>0.05)$. Evaluation of PRA in connection with potato maturity classes did not show advantage to any of them, an average PRA of Early, Mid_early or Mid_late_late classes did not differ significantly $(\mathrm{p}=0.985)$.

The results show that pure protein content ranged from $50 \%$ to $90 \%$ of crude protein content depending on genotypes. Other studies showed significant correlation between PRA and pure protein (Barta \& Bartova, 2008). The relationships between patatin relative abundance, crude protein and pure protein in this study are shown in Figure 4. 


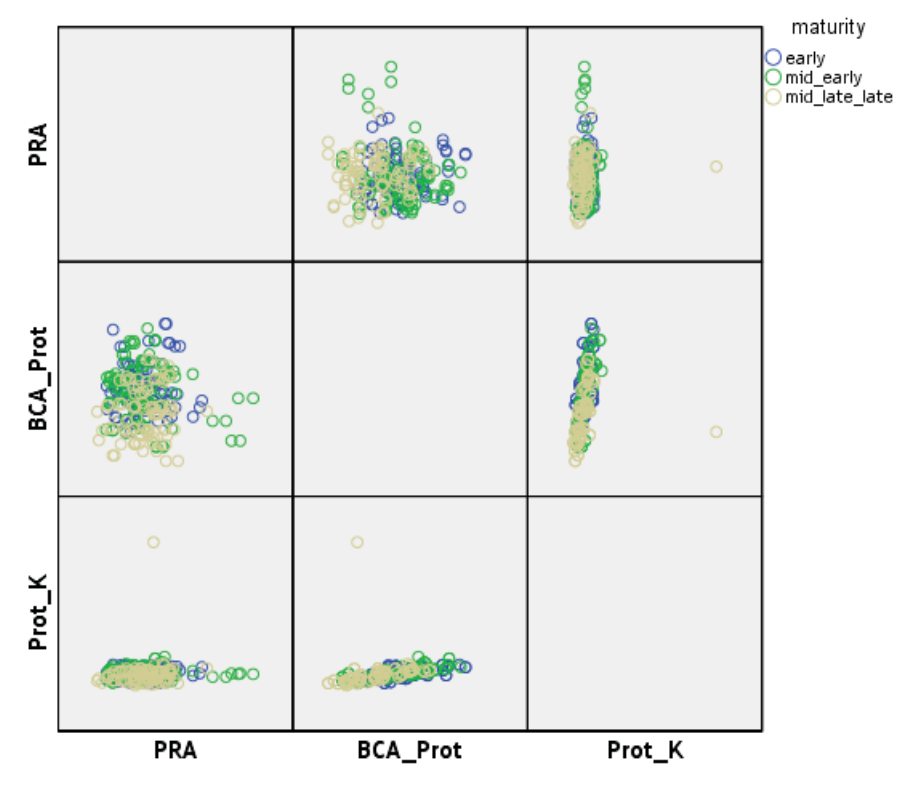

Figure 4. The scattering of patatin relative abundance (PRA) in connection with protein content (Prot_K is crude protein, BCA_prot is pure protein).

Strong positive correlation between crude protein and pure protein $r=0.713(p<0.05)$ and weak negative correlation $\mathrm{r}=-0.211 \quad(\mathrm{p}<0.05)$ between PRA and pure protein was determined in this study. It can be related to varietal characteristics - patatin accumulation ability, heterogeneous structure of patatin, as well as maturity class.

\section{Conclusions}

Patatin determination method by Chip electrophoresis was aprobated, comparable and repeatable results were obtained. Patatin determination area was 40 - $48 \mathrm{kDa}$, which corresponds to other research results on detection area of group of patatin isoforms. Uncertainty of metod was determined $8 \quad 10 \%$ and was recognized as valid for comparison of genotypes. The results of one-year study showed that patatin relative abundance of different cultivars varied from $1.65 \%$ to $50.2 \%$ and was significantly different between genotypes. The farming system, plant available nitrogen content in soil and maturity class of potato did not affect PRA significantly. These results inspired for further research in comparison of potato varieties and improving of protein quality.

\section{References}

Barta, J., \& Bartova, V. (2008). Patatin, the major protein of potato (Solanum tuberosum L.) tubers, and its occurrence as genotype effect: Processing versus table potatoes. Czech Journal of Food Sciences, 26(5), 347359.Bárta, J., Bártová, V., Zdráhal, Z., \& Šedo, O. (2012). Cultivar Variability of Patatin Biochemical Characteristics: Table versus Processing Potatoes (Solanum tuberosum L.). Journal of Agricultural and Food Chemistry, 60(17), 43694378.
https://doi.org/10.1021/jf3003448Bártová, V., Diviš, J., Bárta, J., Brabcová, A., \& Švajnerová, M. (2013). Variation of nitrogenous components in potato (Solanum tuberosum L.) tubers produced under organic and conventional crop management. European Journal of Agronomy, 49, 2031.

https://doi.org/10.1016/j.eja.2013.02.009Camire, M. E., Kubow, S., \& Donnelly, D. J. (2009). Potatoes and human health. Critical Reviews in Food Science and Nutrition, 49(10), 823840.

https://doi.org/10.1080/10408390903041996Delaplace, P., Van Der Wal, F., Dierick, J. F., Cordewener, J. H. G., Fauconnier, M. L., Du Jardin, P., \& America, A. H. P. (2006). Potato tuber proteomics: Comparison of two complementary extraction methods designed for 2-DE of acidic proteins. Proteomics, 6(24), 64946497. https://doi.org/10.1002/pmic.200600493Fu, Y., Liu, W. N., \& Soladoye, O. P. (2020). Towards potato protein utilisation: insights into separation, functionality and bioactivity of patatin. International Journal of Food Science and Technology, 55(6), 23142322

https://doi.org/10.1111/ijfs.14343Kärenlampi, S. O., \& White, P. J. (2009). Potato proteins, lipids, and minerals. In Singh \& Kaur (Eds.), Advances in potato chemistry and technology (pp.99125). Elsevier.Lachman, J., Hamouz, K., Dvořák, P., \& Orsák, M. (2005). The effect of selected factors on the content of protein and nitrates in potato tubers. Plant, Soil and Environment, 51(10), 431438. https://doi.org/10.17221/3614-pseLee, L., Hannapel, D., Mignery, G., Shumway, J., \& Park, W. (1983). Control of tuber protein synthesis in potato. Cellular and Molecular Biology of Plant Stress (USA). New York.Lehesranta, S. J., Koistinen, K. M., Massat, N., 
Davies, H. V, Shepherd, L. V. T., McNicol, J. W., ... Kärenlampi, S. O. (2007). Effects of agricultural production systems and their components on protein profiles of potato tubers. Proteomics, 7(4), 597604.Murniece, I., Kruma, Z., Skrabule, I., \& Vaivode, A. (2013). Carotenoids and Phenols of Organically and Conventionally Cultivated Potato Varieties. International Journal of Chemical Engineering and Applications, 4(5), 342348. https://doi.org/10.7763/ijcea.2013.v4.322Murniece, Irisa, Karklina, D., Galoburda, R., Santare, D., Skrabule, I., \& Costa, H. S. (2011). Nutritional composition of freshly harvested and stored Latvian potato (Solanum tuberosum L.) varieties depending on traditional cooking methods. Journal of Food Composition and Analysis, 24(45), 699710. https://doi.org/10.1016/j.jfca.2010.09.005Pots, A. M., Gruppen, H., Van Diepenbeek, R., Van Der Lee, J. J., Van Boekel, M. A. J. S., Wijngaards, G., \& Voragen, A. G. J. (1999). The effect of storage of whole potatoes of three cultivars on the patatin and protease inhibitor content; a study using capillary electrophoresis and MALDI-TOF mass spectrometry. Journal of the Science of Food and Agriculture, 79(12), 15571564. https://doi.org/10.1002/(SICI)1097-

0010(199909)79:12<1557::AID-JSFA375>3.0.CO;2-
KRuža, A., Skrabule, I., \& Vaivode, A. (2013). Influence of nitrogen on potato productivity and nutrient use efficiency. Proceedings of the Latvian Academy of Sciences, Section B: Natural, Exact, and Applied Sciences, 67(3), 247253.

https://doi.org/10.2478/prolas-2013-0043Skrabule, I., Muceniece, R., \& Kirhnere, I. (2013). Evaluation of Vitamins and Glycoalkaloids in Potato Genotypes Grown Under Organic and Conventional Farming Systems. Potato Research, 56(4), 259276. https://doi.org/10.1007/s11540-013-9242-0Skrabule, I., Piliksere, D., Vaivode, A., \& Dimante, I. (2013). Audzēšanas tehnoloǵijas ietekme uz kartupeḷu ražas kvalitāti (Quality of potato yield as affected by cropping system). Lauksaimniecības Zinātne Veiksmīgai Saimniekošanai, Zinātniski Praktiskās Konferences Raksti, 6064.Waglay, A., Karboune, S., \& Khodadadi, M. (2016). Investigation and optimization of a novel enzymatic approach for the isolation of proteins from potato pulp. LWT - Food Science and Technology, 65, 197205.

https://doi.org/10.1016/j.lwt.2015.07.070

\section{Acknowledgment}

The authors would like to thank PhD.V. Bártová, Department of Plant Production, Faculty of Agriculture, University of South Bohemia, Czech Republic, for sharing the knowledge on patatin detection methods in potato tubers.

The research was funded by the Latvian Council of Science, project "Potato breeding for low input and organic farming systems: nitrogen use efficiency and quality aspects of potato protein", No. lzp-2019/1-0371. 